\title{
Influence of tidal eddies and wind on the distribution of presettlement fishes around One Tree Island, Great Barrier Reef
}

\author{
Scott C. Burgess ${ }^{1,3}$, Michael J. Kingsford ${ }^{1, *}$, Kerry P. Black ${ }^{2}$ \\ ${ }^{1}$ School of Marine and Tropical Biology, James Cook University, Queensland 4811, Australia \\ ${ }^{2}$ ASR Ltd, PO Box 13048, Hamilton, New Zealand
}

${ }^{3}$ Present address: School of Integrative Biology, University of Queensland, Brisbane, Queensland 4072, Australia

\begin{abstract}
Tidally generated eddies that form behind reefs are potentially important physical mechanisms of retention for coral reef fishes during their presettlement phase. The re-circulating properties of eddies may reduce the potential for dispersing fishes to be transported away from settlement habitat and influence patterns of connectivity among adult populations; however, empirical evidence is lacking. We identified the presence of eddies at One Tree Island (OTI) and sampled presettlement fishes in surface waters using a stratified sampling design based on the presence or absence of eddies as predicted from a calibrated hydrodynamic model of the Capricorn-Bunker region. Higher concentrations of presettlement fishes, mostly mullids (goatfishes), were found in the vicinity of the reef in locations where eddies were known to form rather than in locations without eddies, and this was consistent among days and tidal cycles. Locations where eddies were not predicted to form consistently had low concentrations of presettlement fishes. This pattern also occurred under a range of wind strengths and directions. There was evidence for an effect of the windward side of the reef, but areas with eddies maintained high concentrations even when on the leeward side. Higher concentrations were not necessarily found in the eddy itself; rather, they occurred at locations where eddies were predicted to form on the flood or ebb tide. Eddies increase the probability that presettlement fishes will stay near reefs through retention, in some cases their natal reef. Late-stage presettlement fishes are highly mobile and can respond to cues from the reef. Eddies may also increase behavioural interactions among fishes and assist in the detection of reefs that may elicit settlement behaviour.
\end{abstract}

KEY WORDS: Phase eddies · Presettlement fishes · Retention · Connectivity · Coral reefs · Great Barrier Reef

\section{INTRODUCTION}

The scales of connectivity among local populations of coral reef fishes are increasingly regarded as being smaller than expected when considering pelagic larval duration and mainstream currents alone (e.g. Leis 2002, Warner \& Cowen 2002). Because adults are relatively sedentary, processes that occur during their pelagic presettlement phase will determine the degree of connectivity among local populations and the scale at which local production is coupled with recruitment (Cowen et al. 2000). During this presettlement phase (sensu Kingsford et al. 2002), fishes are exposed to a variety of oceanographic features, some of which can deliver them to (e.g. Sponaugle et al. 2005) or retain them near the vicinity of settlement habitat (Kingsford et al. 1991, Cowen \& Castro 1994, Cowen 2002, Leis \& McCormick 2002). In addition, throughout their presettlement phase, fishes develop swimming and sensory abilities that may allow the detection and directed 
movement towards settlement habitat (Atema et al. 2002, Kingsford et al. 2002, Leis et al. 2002). Reduced larval dispersal through physical and biological mechanisms, sometimes leading to substantial selfseeding events (Jones et al. 1999, 2005, Swearer et al. 1999), is thought to be more common than previously realised, and this has important implications for the dynamics and management of fish populations on coral reefs.

Eddies forming behind reefs and islands are potentially an important physical mechanism of retention and reduced connectivity, because their recirculating properties trap and maintain the position of propagules near reefs (Black 1988). When a current encounters an abrupt change in bathymetry (e.g. reef or island), it diverges to flow around the obstruction and recirculating eddies can form in the lee. These topographically generated eddies form at a variety of spatial and temporal scales, ranging from $100 \mathrm{~s}$ of $\mathrm{km}$ for several weeks (e.g. Lobel \& Robinson 1986) to 10s of $\mathrm{m}$ for several hours (Alldredge \& Hamner 1980, Black \& Gay 1987). However, eddies that form near larger oceanic islands surrounded by deep water (e.g. Barbados, Cowen \& Castro 1994) generally occur in unidirectional currents and are larger, more stable and persistent than eddies forming behind smaller reefs in relatively shallow continental shelf environments where tidal currents are strong.

The Great Barrier Reef (GBR) is a mosaic of some 2600 reefs of different shapes and sizes in a shallow continental shelf environment that generates complex patterns of flow, to which presettlement fish are subjected. Waters in the vicinity of coral reefs are strongly influenced by tidal currents, which generate dynamic patterns of eddies. These types of eddies have been termed 'phase eddies' (Black \& Gay 1987) and typically last for about 2 to $3 \mathrm{~h}$ in reversing tidal flows. Phase eddies form just prior to when tidal flow in inter-reef waters peaks and after the change in sea level gradient (Black \& Gay 1987). Recirculation in the eddy continues to strengthen until it dissipates with the onset of the tidal current from the opposite direction, where the same process generally occurs with an eddy forming on the other side of the reef. These circulations potentially transport particles around/through the reef several times over a period of days, effectively trapping them in the immediate vicinity of the reef and preventing them being swept away by far-field currents (Black et al. 1990, 1991). Such eddies are common on the GBR and have been described at islands (e.g. Wolanski et al. 1984), headlands (Alldredge \& Hamner 1980), and coral reefs (Hamner \& Hauri 1981, Sammarco \& Andrews 1988, Wolanski et al. 1984, Young et al. 1993).

There are 2 important features of these tidal eddies that can facilitate the retention of reproductive prod- ucts around reefs in the GBR. Firstly, over several tidal cycles, eddies have the effect of reducing the net transport of particles from the reef, because they essentially move water against the direction of the upstream tidal current and return the particles to a point of origin. This reduces the rate at which those particles are swept from the reef by currents such as the East Australian Current and wind-driven currents. Black (1988) demonstrated with eddy-resolving reef-scale numerical models that relatively higher abundances of larvae should be found in zones where eddies form. These eddies are capable of trapping larvae near the reef for several days (Black et al. 1991), which can be a significant portion of the presettlement phase for some coral reef species. Areas around a reef that retain more larvae than others may also be recruitment hotspots, at least for some invertebrates (Black \& Moran 1991, Sammarco \& Andrews 1998). Secondly, the convergences at the edges of eddies can aggregate meroplankton and function as a transport mechanism (Willis \& Oliver 1988, Wolanski \& Hamner 1988, Kingsford et al. 1991). These convergences form from secondary $3-$ dimensional circulation, where bottom friction and rotation cause water near the bottom to flow radially towards the centre of the eddy, upwell in the majority of the eddy and downwell in a narrow zone towards the edges of the eddy where there is a vertical velocity shear with the free-stream currents (Wolanski et al. 1984).

The physical description of phase eddies and their potential for retention are well known (Wolanski et al. 1984, Black 1988, Cowen 2002), but there are few direct field tests of their influence on the distribution of plankton around coral reefs, especially for presettlement reef fishes. Our objective was to determine the patterns of distribution of presettlement fishes near One Tree Island (OTI) in relation to phase eddies. If phase eddies retained larvae as theory predicts, then we expected areas where eddies formed to have higher concentrations of presettlement fishes than other areas where eddies did not form, and that this would be consistent among days, tidal cycles and different wind conditions. We based our sampling design on the presence or absence of eddies that were predicted from a calibrated, spatially explicit, numerical model of tidal circulation around OTI and surrounding reefs. We also present the results from a simulated release of surface particles in the hydrodynamic model, which we used to relate to the observed distribution of presettlement fishes. Because late-stage presettlement fishes have the potential to influence their own distribution through behaviour, we considered taxa as either passive (e.g. gelatinous zooplankton, preflexion fishes) or potentially active (postflexion fishes). 


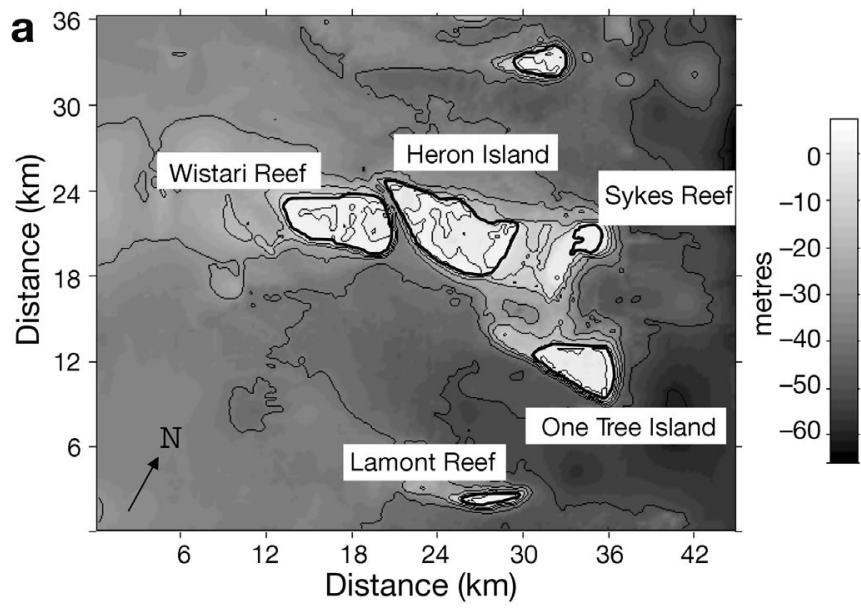

b

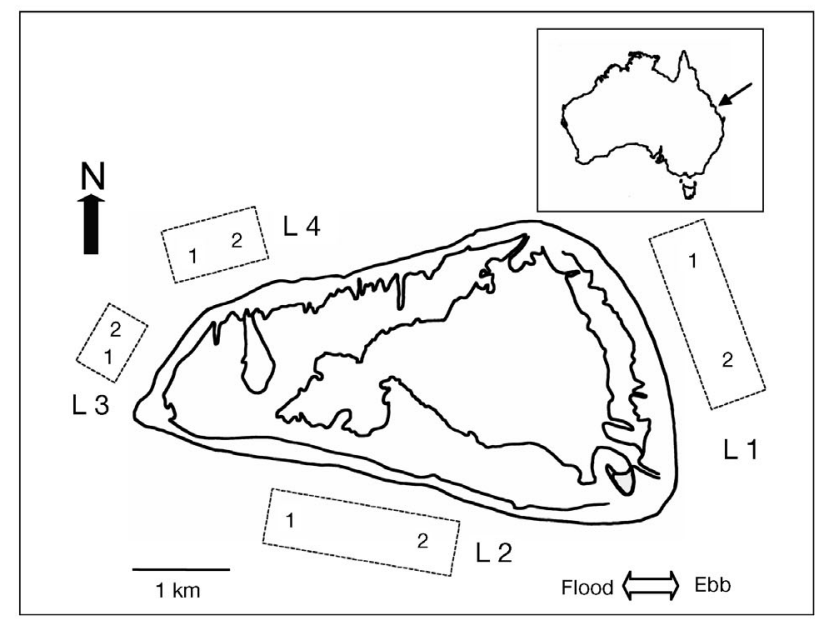

Fig. 1. (a) Position of One Tree Island in relation to surrounding reefs and depth $(\mathrm{m})$; thick lines highlight reef edges. (b) Sampling design and positions of 4 sampling locations (L1 to L4), each with 2 sites separated by 0.5 to $1.5 \mathrm{~km}$. L1 and L2: 'eddy' locations; L3 and L4: 'no eddy' locations

\section{MATERIALS AND METHODS}

Sampling for presettlement fishes took place between 13 and 25 January 2002 at OTI $\left(23^{\circ} 30^{\prime} \mathrm{S}\right.$, $152^{\circ} 06^{\prime} \mathrm{E}$ ). OTI is 1 of 14 reefs in the Capricorn Bunker Group in the southern GBR. OTI is situated $90 \mathrm{~km}$ from the Queensland coast and 5 to $10 \mathrm{~km}$ south-east of neighbouring Heron and Sykes reefs (Fig. 1a).

Acoustic Doppler Current Profiler (ADCP; Falmouth Scientific) and S4 current meters were deployed over a period of $18 \mathrm{~d}$ from 12 to 29 January 2001 as part of an earlier oceanographic study (Haskew 2002, M. Kingsford \& K. Black unpubl. data). Drogues were also released and tracked throughout this period. Fluorescent tracer (Environmental Tracing Systems) was also released and tracked for several days (M. Kingsford \& K. Black unpubl. data). All these data were used to calibrate a depth-integrated numerical model of tidal circulation around OTI and surrounding reefs. More detailed information on the oceanographic study and modelling are in preparation (M. Kingsford \& K. Black unpubl. data). To simulate the circulation, the hydrodynamic model 3DD was adopted from the 3DD Suite of Numerical Models (Black 1995). This model has been used for previous studies of the GBR (e.g. Sammarco \& Andrews 1988, Black et al. 1990, 1991, Black \& Moran 1991). Briefly, sea levels were generated from tidal simulations of the Capricorn-Bunker region using a coarse grid model $(750 \mathrm{~m}$ cell size) including the Queensland coastline and the edge of the continental shelf. These sea levels were then used as boundary conditions to force a nested, fine grid model $(300 \mathrm{~m}$ cell size) of OTI and surrounding reefs. Therefore, tidal circulation patterns around OTI incorporated the influence of neighbouring reefs. Wind data were obtained from the Heron Island weather station. To allow easier visualisation of any wind effects, hourly wind data are presented as the direction that wind was travelling to for the period of time that plankton samples were collected.

Four locations around the perimeter of OTI were sampled for presettlement fishes (Fig. 1b). The positioning of these locations was based on the predicted presence or absence of eddies determined from numerical modelling and current meter data. Location 1 (eastern reef face) was positioned in an ebb-tide eddy. Location 2 (southern reef face) was positioned in a flood-tide eddy. Locations 3 and 4 were positioned in areas characterised by lateral flow during flood and ebb tides. We sampled at 2 sites (separated by $\sim 0.5$ to $1.5 \mathrm{~km}$ ) within each location to allow for potentially patchy distributions; $\mathrm{n}=2$ at each site. All locations were situated away from areas where lagoonal plume water is known to advect during ebb tides, in order to avoid the potential for distribution patterns to be confounded by fish being attracted to or avoiding plume water (Doherty et al. 1996, Booth et al. 2000, Atema et al. 2002). There are also great differences in water visibility between plume and ocean sites that could influence catch rates in nets and confound findings.

All 4 locations were sampled twice on each day of sampling: once during the flood tide and once during the ebb tide. Six days of data are presented; however, due to unworkable weather on the third day (15 January), only the flood tide could be sampled. The 4 locations were sampled during an ebb tide several days later, when weather conditions permitted. Sampling started $2 \mathrm{~h}$ after the change in tide and ended at the following tidal change, so the 4 locations were sampled within $\sim 4 \mathrm{~h}$. Sampling was based on the maximum number of replicates that could be collected in 1 tidal cycle. Every attempt was made to sample the locations 
in a random order to avoid systematic temporal bias. All tows were within $1 \mathrm{~km}$ of the reef edge.

Presettlement fishes were collected with a squaremouth $(0.75 \times 0.75 \mathrm{~m})$ box-pyramid designed net with a mesh size of $500 \mu \mathrm{m}$ (Kingsford \& Murdoch 1998). Due to the time constraints imposed by the sampling design, the net was towed for 3 min in surface waters (including the neuston). Towing at a single depth also allowed for more accurate estimates of abundance for taxa that occur in surface waters only. A General Oceanics Flowmeter 2030 was used to estimate volumes of water sampled for each tow. The average volume of water filtered per tow was $159 \mathrm{~m}^{3}\left(\mathrm{SD}=35 \mathrm{~m}^{3}\right)$ and the net was towed at 1.2 to $1.6 \mathrm{~m} \mathrm{~s}^{-1}$. At the completion of a tow, the contents of the cod-end were decanted into jars containing 2 to $5 \%$ formalin.

All fishes were removed from the sample with the aid of a dissecting microscope and identified to the lowest possible taxonomic level. Most fishes could be identified to family and some to genus. Fishes were also categorised as preflexion or postflexion. Flexion stage fishes were categorised as preflexion fishes. Gelatinous zooplankton were identified and their volumes measured in the field. Fish data are expressed as ind. $150 \mathrm{~m}^{-3}$, as this is approximate to the average volume of water sampled in each tow. Data on fish concentrations were analysed using a fully hierarchical ANOVA to assess variation between and within eddy and no eddy areas. Locations 1 and 2 were treated as 'eddy' areas on flood and ebb tides, and Locations 3 and 4 were treated as 'no eddy' areas. This was performed for each tide of each day to avoid temporal correlation. Sites (2) were nested in locations (2), which were nested in hydrography (eddy/no eddy). The ANOVA assumption of homogeneity of variance was tested using a Cochran's test and, where significant, data were $\ln (x+1)$-transformed. This hierarchical approach allowed us to calculate variance components. Variance components were particularly important for hydrology, because separate analysis resulted in low degrees of freedom for this factor. The proportion of variation explained by each factor was examined by calculating variance components for total mullids, preflexion and postflexion mullids from untransformed data.

In order to investigate the retention ability of the tidal eddies at OTI, and to help explain observed patterns of distribution, passive particles were released into the model in a square with edges approx. $4 \mathrm{~km}$ from the reef edge and allowed to drift for $219 \mathrm{~h}$ (9.125 d). The particle modelling was undertaken using the Lagrangian model POL3DD from the full 3DD suite, which has been used for both passive and active larval studies (e.g. Sammarco \& Andrews 1988, Jenkins et al. 1999). It treats the organisms as particles that are advected with the currents, and predicts the zones of highest retention by logging particle positions throughout the simulations ('integrated particle numbers'). We used this to examine the overall influence of the eddies around the outside of the reef by integrating all positions at each $200 \mathrm{~s}$ time step over the full model simulation.

\section{RESULTS}

\section{Tidal circulation around OTI}

Eddies formed on the southern and eastern reef faces with the flood and ebb tide, respectively (Fig. 2). As the tide flooded in from the east it encountered the eastern reef face and diverged to flow around the reef. The reef shape and orientation to the flood tidal current was such that water passed along the northern reef edge parallel to the reef. The south-eastern corner of OTI created an obstruction that was sufficient

\section{(a) Flood tide}
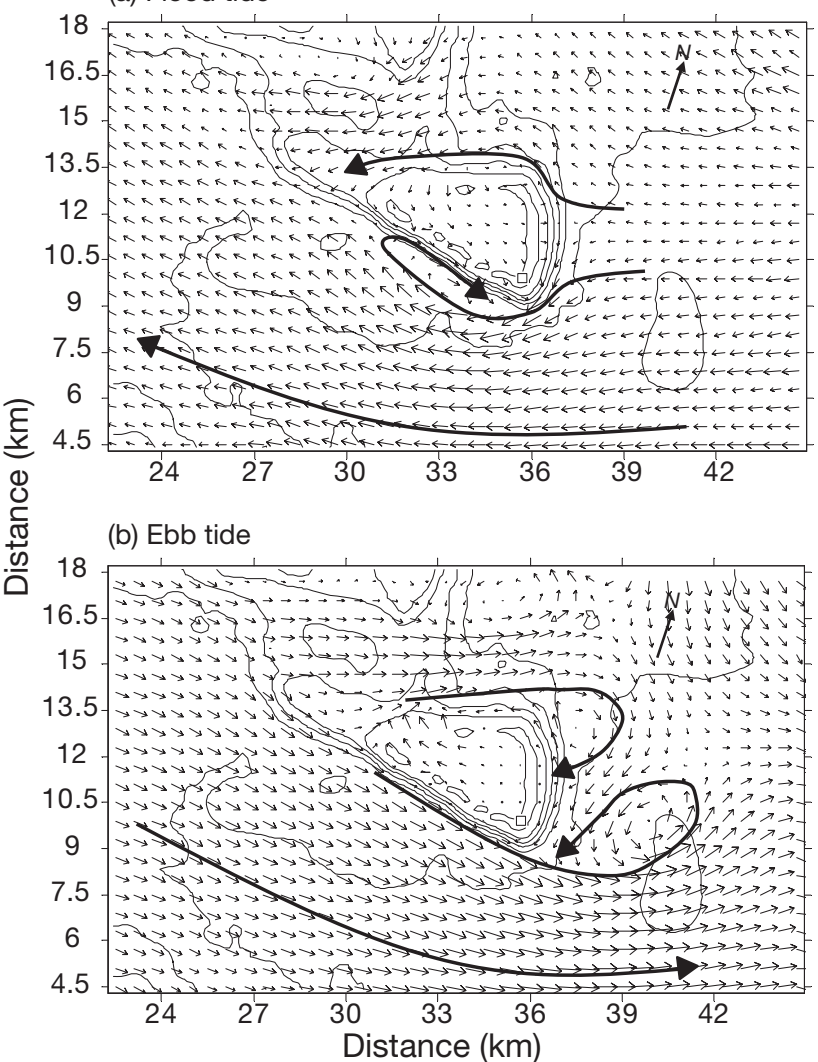

Fig. 2. Vector plots from a numerical model showing typical formation of eddies at One Tree Island at (a) $6 \mathrm{~h}$ into a flood tide $(0.5 \mathrm{~h}$ before the change in tide) and (b) $5 \mathrm{~h}$ into an ebb tide (1.5 $\mathrm{h}$ before the change in tide). Depicted eddies occurred during spring tides; thick arrows indicate generalised particle trajectories over a single tide (approx. $6 \mathrm{~h}$ ) 
enough to cause an eddy along the southern reef face during flood tides. During the ebb tide, in which the current flows from the west in the opposite direction to the flood tide, there was no eddy along the southern reef face and water flowed parallel to the reef edge. During the ebb tide, eddies formed on the eastern reef face. During the strong tidal currents associated with spring tides, 2 eddies typically formed. One smaller eddy formed at the northern end of the eastern reef face and the other, slightly larger eddy formed at the southern end and marginally further away from the reef edge (Fig. 2). During weaker ebb flows associated with neap tides, the north-eastern eddy was not always as defined on the eastern reef face, where circulation was dominated by the more southern, counter-clockwise rotating eddy. Both flood and ebb eddies persisted for $\sim 4 \mathrm{~h}$ and were most defined during the second half of the tidal cycle (M. Kingsford \& K. Black unpubl. data). During tidal transitions, the eddies lost their momentum after the gradient in sea level changed, and dissipated with the onset of tidal currents from the opposite direction. Eddy regions were clearly distinguished from regions where eddies did not form.

\section{Presettlement fish distributions}

During the $6 \mathrm{~d}$ of sampling, more than 8000 fishes were caught representing 46 families. Forty-five percent of the total fishes caught were preflexion fishes. Mullids (goatfishes) dominated the catches, comprising $51 \%$ (28\% postflexion and $23 \%$ preflexion), and had a large influence on general patterns of abundance of total fishes. Postflexion carangids (10\%), juvenile atherinids (4\%), preflexion microdesmids $(3 \%)$, and preflexion engraulids $(2 \%)$ were the next most common taxa. The concentrations and frequency of occurrence of the majority of taxa were too low for meaningful comparisons. Therefore, we have only presented the distribution patterns for mullids. Because mullids are known to have highest abundances in surface waters (top few metres) especially during the day (Kingsford 1988, Leis 1991, McCormick \& Milicich 1993), they provide a suitable taxa to explore surface water patterns.

On 11 out of the 12 sampling occasions, concentrations of pre- and postflexion fishes were always highest at sites that were located on the southern and eastern reef faces where tidal eddies were predicted to form (Fig. 3). The concentration of preflexion mullids in each tow was positively related to the concentrations of postflexion mullids ( $\mathrm{df}=$ $\left.190, \mathrm{r}^{2}=0.453, \mathrm{p}<0.01\right)$, despite the potential for them to be active and determine their own position, and were subsequently pooled for presentation. The eddyrelated pattern of distribution was also observed for all taxa when pooled. A few samples were collected after sundown or before sunrise, but had no influence on the overall patterns of abundance around the reef (Days 1 and 2 flood, Day 3 ebb). Patterns of relative concentration of mullids were consistent among the $6 \mathrm{~d}$ of sampling, such that at least 1 site on the southern or eastern side of the reef always had highest concentrations.

Importantly, highest concentrations were not necessarily found in the eddy itself. There appeared to be a residual effect of eddies on the southern and eastern sides. On most days, there were few differences in the relative distribution patterns of mullids in surface waters between flood and ebb tides. For example, on flood tides, concentrations were not always highest along the southern reef face (Location 2) and, on ebb tides, concentrations were not always highest along the eastern reef face (Location 1).

Despite the intrinsic patchiness of larval fish distributions, consistently higher concentrations of total mullids were observed in eddy locations than in no eddy locations (all sites), and these differences were significant on 3 out of the 12 sampling occasions (Table 1). On most occasions, consistent differences between areas of eddies and no eddies still explained much variation for total, preflexion, and postflexion mullids (Table 2 ). Variance components of total mullids for eddy vs. no eddy were similar for ebb (average $35 \%$, Table 2) and flood tides (average 32\%). Concentrations were also patchy within eddy locations (Fig. 3), and this was reflected in differences among sites (Tables 1 \& 2). Average residual variance was 15 and $30 \%$ for flood and ebb tides, respectively, but was greater than $70 \%$ on some occasions, indicating extreme patchiness at times. On some occasions, the highest concentration was

Table 1. Mean square estimates from hierarchical ANOVA for concentrations of total mullids for each tide on each of $6 \mathrm{~d}$. Data were $\ln (x+1)$-transformed. ${ }^{*} \mathrm{p}<0.05,{ }^{* *} \mathrm{p}<0.01,{ }^{* * *} \mathrm{p}<0.001$

\begin{tabular}{|lccccccc|}
\hline & df & Day 1 & Day 2 & Day 3 & Day 4 & Day 5 & Day 6 \\
\hline Flood tide & & & & & & & \\
Hydro & 1 & 6.08 & 13.28 & $36.48^{*}$ & 27.26 & 22.34 & 24.80 \\
Location (H) & 2 & 7.22 & $14.70^{*}$ & 1.37 & 0.61 & 1.96 & 1.74 \\
Site (L(H)) & 4 & 1.17 & 1.33 & 0.86 & $0.34^{* *}$ & $0.44^{*}$ & $2.05^{* *}$ \\
Residual & 8 & 0.55 & 0.44 & 0.37 & 0.04 & 0.10 & 0.15 \\
Ebb tide & & & & & & & \\
Hydro & 1 & 0.21 & 38.07 & 36.12 & $24.82^{* *}$ & 32.53 & $4.05^{*}$ \\
Location (H) & 2 & 0.47 & 4.84 & $2.66^{* *}$ & 0.17 & $1.97^{* * *}$ & 0.06 \\
Site (L(H)) & 4 & 0.60 & 0.74 & 0.06 & 0.72 & 0.01 & 0.15 \\
Residual & 8 & 0.71 & 0.95 & 0.23 & 0.14 & 0.03 & 0.20 \\
\hline
\end{tabular}


caught at only one eddy location. Sites along the northern and eastern reef face in no eddy areas consistently had low concentrations of mullids and less patchiness between locations and sites $\left(<10\right.$ ind. $150 \mathrm{~m}^{-3}$, Fig. 3).
The difference between the site with the highest concentration of mullids to that with the lowest concentration ranged from 22.1 ind. $150 \mathrm{~m}^{-3}$ on Day 6 ebb tide to 216.4 ind. $150 \mathrm{~m}^{-3}$ on Day 2 flood tide. The maximum

(a) Flood tide

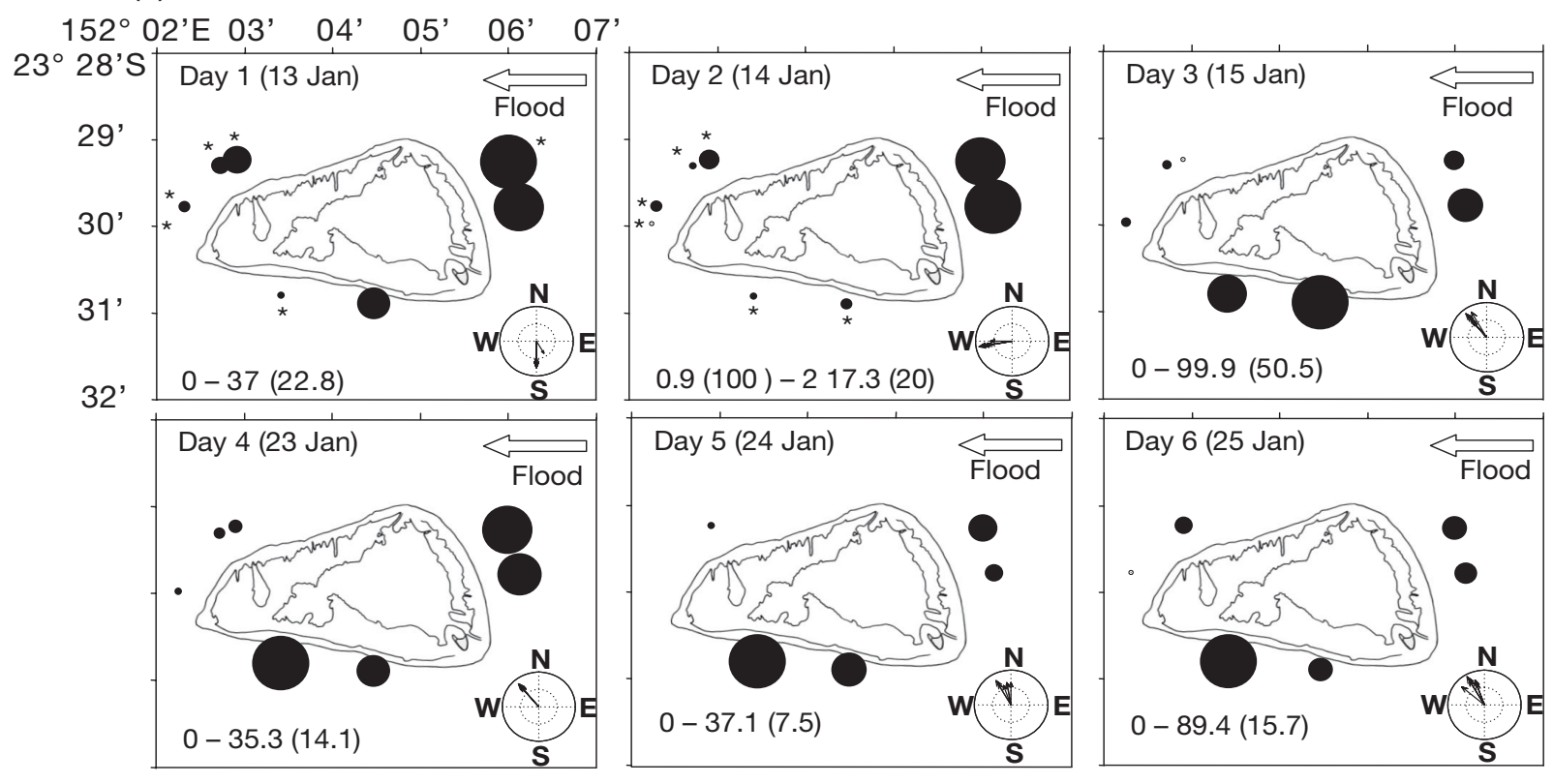

(b) Ebb tide

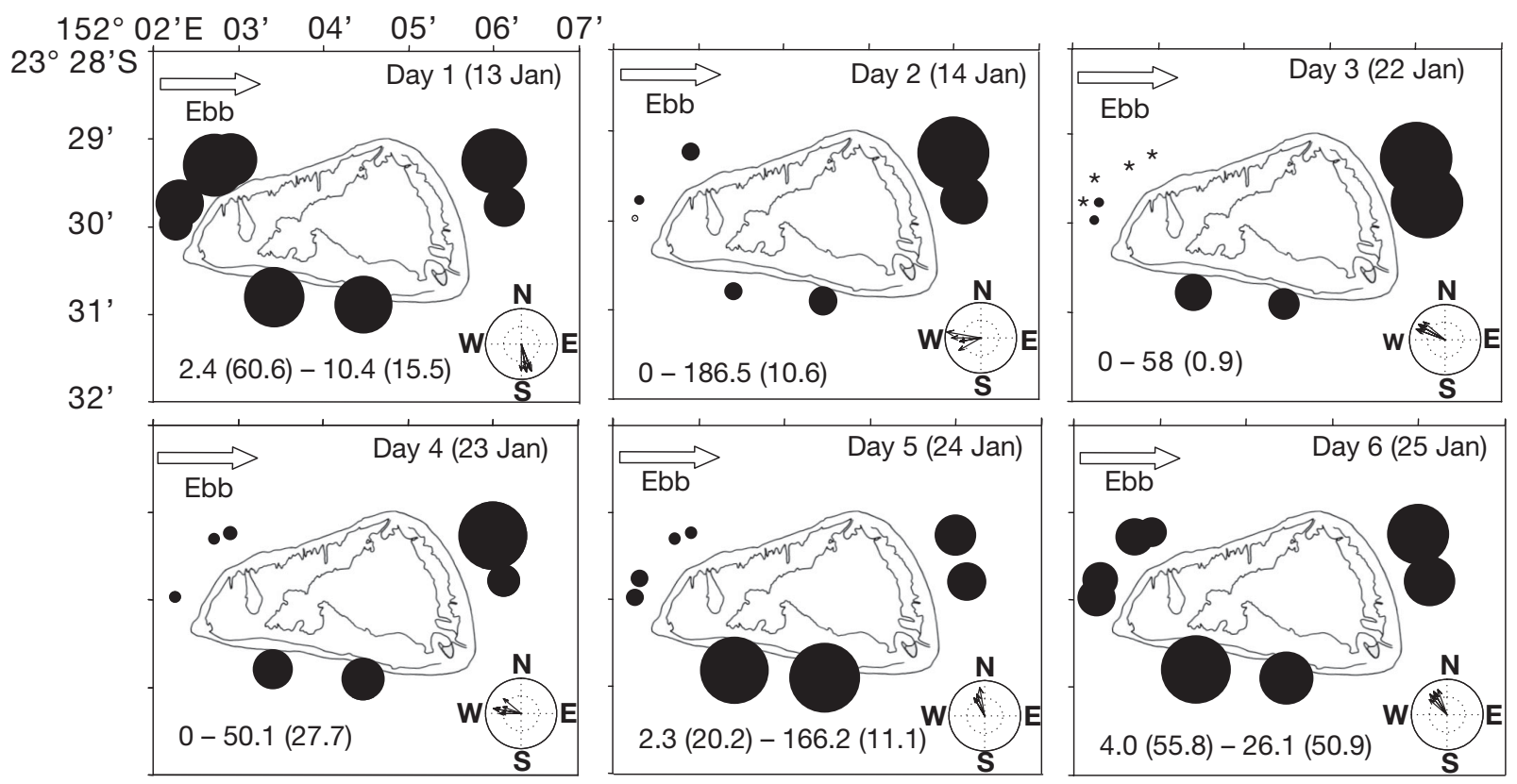

Fig. 3. Distribution of presettlement mullids in surface waters for (a) flood and (b) ebb tides. Preflexion and postflexion mullids were pooled because their distribution patterns where similar. Bubble size represents relative abundance, and range of means (with SE as \% of means in brackets) is presented for each day. Hourly measurements of wind data for the sampling period are presented in the bottom right as the direction that wind is travelling. Arrow length depicts wind speed, with the inner circle representing $5.14 \mathrm{~m} \mathrm{~s}^{-1}$ and the outer $10.29 \mathrm{~m} \mathrm{~s}^{-1}$. New moon was 13 January, and first quarter moon was 22 January. *: samples collected before sunrise $(\sim 05: 30 \mathrm{~h})$ or after sunset $(\sim 18: 30 \mathrm{~h})$ 
Table 2. Percent variation explained by hydrology (eddy/no eddy), location, and site. Variance components calculated from mean squares determined from ANOVA of untransformed data for concentrations of total (Tot), preflexion (Pre) and postflexion (Po) mullids for each tide on each of $6 \mathrm{~d}$

\begin{tabular}{|c|c|c|c|c|c|c|c|c|c|c|c|c|c|c|c|c|c|c|c|c|c|}
\hline \multirow[b]{3}{*}{ Flood tide } & \multicolumn{3}{|c|}{ Day 1} & \multicolumn{3}{|c|}{ Day 2} & \multicolumn{3}{|c|}{ Day 3} & \multicolumn{3}{|c|}{ Day 4} & \multicolumn{3}{|c|}{ Day 5} & \multicolumn{3}{|c|}{ Day 6} & \multicolumn{3}{|c|}{ Grand mean } \\
\hline & Tot & Pre & Po & Tot & Pre & Po & Tot & Pre & Po & Tot & Pre & Po & Tot & Pre & Po & Tot & Pre & Po & Tot & Pre & Po \\
\hline & & & & & & & & & & & & & & & & & & & & & \\
\hline Hydro & 13 & 0 & 18 & 0 & 5 & 0 & 42 & 37 & 59 & 77 & 51 & 68 & 34 & 19 & 39 & 27 & 16 & 32 & 32 & 21 & 36 \\
\hline Location $(\mathrm{H})$ & 50 & 50 & 43 & 91 & 78 & 93 & 17 & 14 & 22 & 0 & 22 & 0 & 27 & 49 & 5 & 4 & 0 & 15 & 32 & 36 & 30 \\
\hline Site $(\mathrm{L}(\mathrm{H}))$ & 0 & 0 & 0 & 1 & 6 & 0 & 8 & 9 & 8 & 21 & 3 & 26 & 35 & 20 & 25 & 62 & 69 & 46 & 21 & 18 & 17 \\
\hline Residual & 36 & 50 & 39 & 8 & 11 & 7 & 33 & 39 & 12 & 3 & 24 & 6 & 4 & 12 & 31 & 7 & 16 & 7 & 15 & 25 & 17 \\
\hline Ebb tide & & & & & & & & & & & & & & & & & & & & & \\
\hline Hydro & 0 & 0 & 0 & 20 & 8 & 34 & 30 & 30 & 30 & 52 & 12 & 75 & 52 & 73 & 39 & 57 & 0 & 49 & 35 & 21 & 38 \\
\hline Location $(\mathrm{H})$ & 4 & 29 & 0 & 49 & 69 & 3 & 51 & 44 & 49 & 0 & 9 & 0 & 47 & 10 & 56 & 0 & 43 & 0 & 25 & 34 & 18 \\
\hline Site $(\mathrm{L}(\mathrm{H}))$ & 0 & 0 & 17 & 25 & 19 & 20 & 0 & 10 & 0 & 37 & 66 & 15 & 0 & 14 & 3 & 0 & 0 & 16 & 10 & 18 & 12 \\
\hline Residual & 96 & 71 & 83 & 6 & 4 & 43 & 19 & 16 & 21 & 11 & 13 & 10 & 2 & 3 & 2 & 43 & 57 & 36 & 30 & 27 & 32 \\
\hline
\end{tabular}

mean concentration at a site on a particular day ranged from $35.3( \pm 14.1)$ on Day 1 ebb tide to $217.3( \pm 20)$ on Day 2 flood tide. Variation within sites was also large on some days, with precision (SE as \% of mean) ranging from $100 \%$ for a low concentration on Day 2 flood to $0.9 \%$ on Day 3 ebb.

Wind appeared to have some effect on neustonic mullids that could be separated from an eddy effect (i.e. on southern and eastern sides). On Day 1 ebb tide, there were winds from the NNW that averaged $7.72 \mathrm{~m}$ $\mathrm{s}^{-1}$ and mullid concentrations were similar between eddy and no eddy sites, even though average concentrations were low ( $\max 10.4$ ind. $150 \mathrm{~m}^{-3}$ ). Despite this potential wind effect, where wind-driven currents may

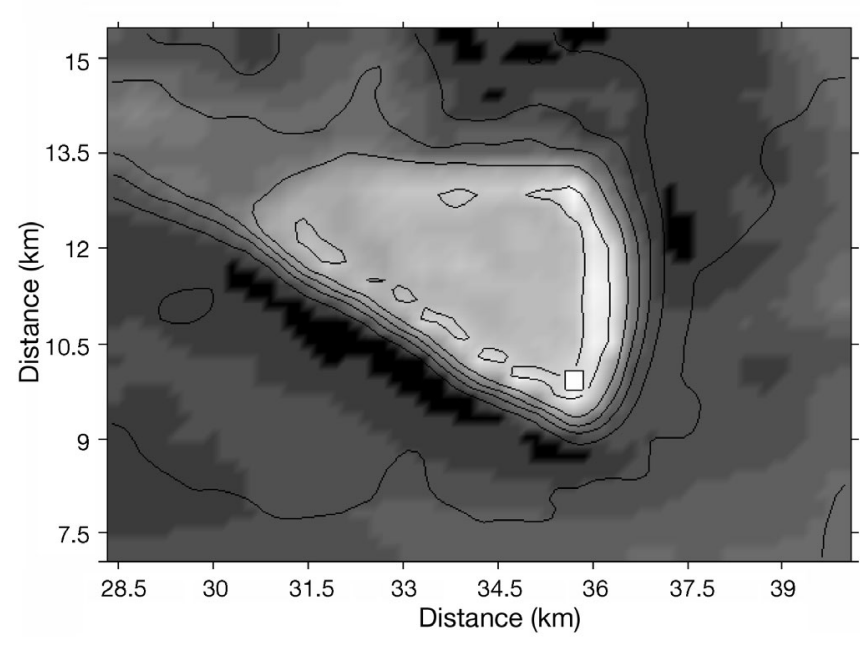

Fig. 4. Model POL3DD simulation: integrated particle numbers after $219 \mathrm{~h}$ from a single release to predict zones of highest retention and examine the overall influence of eddies around One Tree Island. Dark patches show areas where particles pass over more often and indicate areas where retention is likely push presettlement fishes towards the windward reef face and away from the leeward reef face, concentrations of mullids were still as high on the leeward side in predicted eddy areas.

Observed patterns of mullid distribution were similar to the zones of highest retention identified from simulations where passive particles were released in surface waters and allowed to move around with the currents (Fig. 4). On the eastern reef face, the darker patches reflect the trapping of particles by the eddy that forms there during ebb tides, as described earlier. The darker patches on the southern reef face reflect the retention effect of the eddy forming during flood tides. Lighter colours along the northern and western reef faces reflect the lack of retention of particles as a result of non-linear lateral flows. These patterns also occurred when a wind field of actual wind encountered during sampling was included in the simulations. However, patterns derived from these simulations do not necessarily imply that the observed distribution patterns were purely due to passive forcing. Rather, they strengthen the relationship between the observed patterns of mullids and the predicted presence of phase eddies.

There was no relationship between the concentration of preflexion $\left(\mathrm{r}^{2}=0.054, \mathrm{p}>0.05\right)$ or postflexion $\left(\mathrm{r}^{2}=0.031, \mathrm{p}>0.05\right)$ mullids and the volume of gelatinous zooplankton, which included Aurelia spp., Aequorea spp. and salps. However, these gelatinous zooplankters may influence the distribution of other taxa known to associate with them (e.g. carangids). We found a positive correlation between the concentration of postflexion carangids and the volume of gelatinous zooplankton $\left(\mathrm{r}^{2}=0.371, \mathrm{p}<0.05, \mathrm{n}=820\right.$ fish). Therefore, a combination of current and gelatinous zooplankton may influence the distribution of postflexion carangids. 


\section{DISCUSSION}

Concentrations of presettlement fishes in surface waters around OTI were higher in regions around the reef where eddies were predicted to form during a flood or ebb tide than in other regions where no eddies were predicted. The northern and western reef face at OTI (no eddy) consistently had low surface concentrations of mullids; in contrast, the southern and eastern reef faces (predicted eddy areas) had large fluctuations among days and tides, but highest concentrations were consistently found at at least one site. Observed distribution patterns of mullids were consistent with the theory that eddies result in an alteration of particle trajectories that increases the probability of detecting patches, and that it is the combined effect of flood and ebb tide eddies that is important. Tidal eddies in the GBR operate to retain particles because they alter their trajectory, returning them to some origin over several tidal cycles (Black 1988). Therefore, a slower loss of material from the reef occurs in eddy regions, which results in higher concentrations when compared with other regions where expatriation of particles is rapid (Black 1988). Concentration in areas once a phase eddy has degenerated may in part be due to gregarious behaviour of presettlement fish that were retained there due to eddy hydrography and, in some cases, convergence zones of eddy margins (Kingsford et al. 1991).

These patterns of distribution in relation to eddies are consistent with patterns found around coral reefs in other parts of the GBR. Holoplankton have been caught in higher concentrations in tidal eddies behind headlands in the Whitsundays (Alldgredge \& Hamner 1980). Latestage presettlement fishes have been caught in light traps in higher concentrations in zones of low tidally averaged current speeds (Carleton et al. 2001). Positively buoyant coral eggs have been found in higher concentrations in convergence zones (Willis \& Oliver 1988, Wolanski et al. 1989). Other studies have predicted eddy-related distributions of pelagic larvae from recruitment surveys of corals and crown-of-thorns starfish (COTS; Sammarco \& Andrews 1988, Black \& Moran 1991). However, the regions that we sampled were not necessarily zones of low current speed, but zones of eddy recirculation. Average current speed may not be any less than that in the no eddy zones, but the recirculating properties mean that patches of larvae are more likely to be caught in eddy zones because they spend more time in those regions. Far-field current speed may determine if there is a shadow zone of low flushing or a fully developed recirculating tidal eddy. Patches of meroplankton may therefore be more stable in the former than in the latter type of near-reef circulation.

We did not necessarily find highest concentrations of mullids in the predicted eddy zone for a particular tide; rather, highest concentrations occurred where eddies were predicted to form on the flood or the ebb tide. Topographically generated tidal eddies in the GBR are very dynamic, and for these eddies there is no simple relationship between eddy presence and concentration because concentrations can remain in eddy areas after the physical structure has dissipated (i.e. 'the ghost of eddies past'). This contrasts with the patterns observed in geostrophic flows, where larvae are often caught in higher concentrations downstream than upstream (Lobel \& Robinson 1986, Cowen \& Castro 1994). Phase eddies are more short-lived (and usually of smaller size), and it is the combination of all eddies forming in different areas of a reef in reversing tidal currents that reduce net transport away from the reef (Black et al. 1991). The eddy-related patterns of mullid distribution that we observed were not necessarily a result of concentration, where input is greater than output, but rather of trapping, especially for preflexion stages. However, concentration may occur at the edges of eddies in a narrow, downwelling zone for buoyant or upward-swimming larvae (Wolanski \& Hamner 1988).

Patterns of presettlement fish distribution in surface waters would be expected to show the least concordance with the presence of eddies because wind-driven currents could alter the influence of eddies by transporting surface water presettlement fishes out of eddies. That the eddy-related patterns were observed in surface waters under a range of wind conditions suggest that these patterns would persist deeper in the water column where wind has less of an influence. However, to sample deeper in the water column with the spatial and tiderelated resolution of our sampling design would be logistically challenging. Presettlement fishes alter their position in the water column on a diel basis (Kingsford 2001) or ontogenetically (Leis 1991). Some species also appear to show a 'preference' for certain depths (Leis 1991). Mullids appear to show a preference for surface waters, especially 'older' mullids during the day, and only occur in low numbers at depths greater than $\sim 5 \mathrm{~m}$ (Kingsford 1988, Leis 1991). Since the continental shelf environment of the GBR is generally well mixed vertically, most taxa throughout the water column potentially experience the presence of eddies.

Eddy-related distribution patterns of presettlement fishes that are capable of effective swimming do not necessarily imply that they arose from passive drift alone, even though the distribution patterns of postflexion mullids were very similar to those of preflexion mullids (which were thought to have less effective swimming ability). Presettlement fishes capable of effective swimming are often gregarious and may actively maintain their position in areas of higher plankton concentration and in the vicinity of drifting objects. Large gelatinous zooplankton, clumps of algae, or any 
other drifting material may indirectly result in eddy-related patterns of dispersal for fishes, because many postflexion and juvenile presettlement stages school around drifting objects (Kingsford 1993), including mullids (McCormick \& Milicich 1993). There was little drifting material at OTI. Therefore, the presence of drifting material is unlikely to have confounded our eddy-related patterns of mullid abundance. Gelatinous zooplankton can also alter fish distributions; however, we found no relationship between the distribution patterns of gelatinous zooplankton and mullids. In contrast, postflexion carangids were only abundant in the presence of gelatinous zooplankton. This is consistent with previous studies, because carangids are known to associate with drifting objects (Kingsford 1993). A consequence of associating with drifting material that becomes trapped in eddies may therefore be the (perhaps inadvertent) retention near reefs.

Larval concentrations that are higher in waters adjacent to some reef faces than in others may predict recruitment hotspots, especially for those coral reef taxa whose larvae have limited swimming ability and ability to actively seek settlement sites at scales greater than 10s of m. Black \& Moran (1991) found higher abundances of juvenile COTS in areas of reef where eddies form in the immediate vicinity. Sammarco \& Andrews (1988) reported higher coral recruitment onto settlement tiles set up in eddy zones than on those in no eddy zones at Helix reef, central GBR. However, the role of eddies in contributing to recruitment variation around a reef will depend on what scale presettlement reef fish can control their position and determine where to settle. Eddies may be effective in maintaining the position of presettlement reef fishes near a reef, but these fishes show habitat preferences and may actively seek suitable settlement sites over several km (Doherty 1991). For example, mullids generally prefer sandy habitats as adults, and the reef face where eddies form at OTI comprises rock terraces and walls, at least in the top $20 \mathrm{~m}$.

Physical processes alone do not describe connectivity among reefs for populations of reef fishes (Kingsford et al. 2002, Warner \& Cowen 2002). The relative importance of physical vs. biological mechanisms of retention will likely change as presettlement fishes develop (Leis 2002). The role of phase eddies in the dispersal process of reef fishes is probably most important for fish eggs and young larvae. During the latter portion of their pelagic larval phase, retention is probably a result of an interaction between water currents and larval behaviour. Therefore, the probability that reef fishes recruit back to their natal reef will likely depend on whether physical retention occurs early in the presettlement stage and at what point they develop behaviour conducive to settlement (Leis \& McCormick 2002). If physical retention does occur early in their presettlement stage, in many cases they may not have to swim very far to get to their natal reef. Whether or not the mullids observed in our study spent their entire presettlement phase in these eddy regions cannot be determined. Black et al. (1991) demonstrated that currents around some coral reefs have the potential to retain significant amounts of locally released material (e.g. $50 \%$ still retained after 5 d). For other coral reef taxa with more 'passive' larvae (such as corals, COTS and other invertebrates) and shorter pelagic larval durations (e.g. 4 to $5 \mathrm{~d}$ for corals), phase eddies potentially have a more significant influence on population connectivity than that of reef fishes.

In conclusion, we provided evidence that highly dynamic phase eddies can have a major influence on the distribution of presettlement fishes. We show that the 'ghost of eddies past' is still evident despite changes in tide. Although eddies theoretically influence trajectories of particles rather than concentrations, gregarious behaviour of presettlement fishes and related concentrations may be enhanced in eddies and for short periods when the eddy is absent. While we had some evidence of a windward concentration of mullids, concentrations were still as high at the leeward sites in areas where phase eddies were predicted. Drift material can confound interpretations of oceanography, but this was not the case for mullids. Concentration may occur at outer convergences. These features increase the probability that presettlement fishes will stay near reefs, in some cases their natal reef. Late-stage presettlement fish are highly mobile (Stobutzki \& Bellwood 1997, Fisher \& Wilson 2004) and can respond to cues from the reef (Kingsford et al. 2002), and eddies may increase the chance of retention and detection of reefs that elicit settlement behaviour.

Acknowledgements. This research was supported by an ARC grant to M.J.K. and K.P.B. Towing ichthyoplankton nets for multiple days and often in difficult conditions requires a good crew and robust stomachs; we thank the crew of MV 'James Cook' and J. Hughes for assistance in the field. We also thank 3 anonymous reviewers for comments on the manuscript. This is a contribution of the One Tree Island field station and the Fish and Ocean Ecology Laboratory of James Cook University. Research was conducted in accordance with institutional, national (Great Barrier Reef Marine Park Authority Permit) and international guidelines concerning the use of animals in research.

\section{LITERATURE CITED}

Alldredge AL, Hamner WM (1980) Recurring aggregation of zooplankton by the tidal current. Estuar Coast Mar Sci 10: 31-37

Atema J, Kingsford MJ, Gerlach G (2002) Larval reef fish could use odour for detection, retention and orientation to reefs. Mar Ecol Prog Ser 241:151-160 
Black KP (1988) The relationship of reef hydrodynamics to variations in numbers of planktonic larvae on and around coral reefs. Proc 6th Int Coral Reef Symp 2: $125-130$

Black KP (1995) The 3DD suite of numerical physical process models. User manuals. ASR Ltd, Raglan

Black KP, Gay SL (1987) Eddy formation in unsteady flows. J Geophys Res 92:9514-9522

Black KP, Moran PJ (1991) Influence of hydrodynamics on the passive dispersal and initial recruitment of larvae of Acanthaster planci (Echinodermata: Asteroidea) on the Great Barrier Reef. Mar Ecol Prog Ser 69:55-65

Black KP, Gay SL, Andrews JC (1990) Residence times of neutrally-buoyant matter such as larvae, sewage or nutrients on coral reefs. Coral Reefs 9:105-114

Black KP, Moran PJ, Hammond LS (1991) Numerical models show coral reefs can be self-seeding. Mar Ecol Prog Ser $74: 1-11$

Booth DJ, Kingsford MJ, Doherty P, Beretta GA (2000) Recruitment of damselfishes in One Tree Island lagoon: persistent interannual spatial patterns. Mar Ecol Prog Ser 202:219-230

Carleton JH, Brinkman R, Doherty PJ (2001) The effects of water flow around coral reefs on the distribution of presettlement fish (Great Barrier Reef, Australia). In: Wolanski E (ed) Oceanographic processes of coral reefs: physical and biological links in the Great Barrier Reef. CRC Press, Boca Raton, FL, p 209-230

Cowen RK (2002) Larval dispersal and retention and consequences for population connectivity In: Sale PF (ed) Coral reef fishes: dynamics and diversity in a complex ecosystem. Academic Press, San Diego, CA, p 149-170

Cowen RK, Castro LR (1994) Relation of coral reef fish larval distributions to island scale circulation around Barbados, West Indies. Bull Mar Sci 54:228-244

Cowen RK, Lwiza KMM, Sponaugle S, Paris CB, Olson DB (2000) Connectivity of marine populations: open or closed? Science 287:857-859

Doherty P (1991) Spatial and temporal patterns in recruitment. In: Sale PF (ed) The ecology of fishes on coral reefs. Academic Press, San Diego, CA, p 261-293

Doherty P, Kingsford MJ, Booth D, Carleton JH (1996) Habitat selection before settlement by Pomacentrus coelestis. Mar Freshw Res 47:391-399

Fisher R, Wilson SK (2004) Maximum sustainable swimming speeds of late-stage larvae of nine species of reef fishes. J Exp Mar Biol Ecol 312:171-186

Hamner WM, Hauri IR (1981) Effects of island mass: water flow and plankton pattern around a reef in the Great Barrier Reef lagoon, Australia. Limnol Oceanogr 26: 1084-1102

Haskew R (2002) Circulation around One Tree Reef, Great Barrier Reef, Australia. MSc thesis, University of Waikato

Jenkins GP, Black KP, Keough MJ (1999) The role of passive transport and the influence of vertical migration on the pre-settlement distribution of a temperate, demersal fish: numerical model predictions compared with field sampling. Mar Ecol Prog Ser 184:259-271

Jones GP, Milicich MJ, Emslie MJ, Lunow C (1999) Selfrecruitment in a coral reef fish population. Nature 402 : 802-804

Jones GP, Planes S, Thorrold SR (2005) Coral reef fish larvae settle close to home. Curr Biol 15:1314-1318

Kingsford MJ (1988) The early life history of fish in coastal waters of northern New Zealand: a review. NZ J Mar Freshw Res 22:463-479

Editorial responsibility: Howard Browman (Associate Editorin-Chief), Storebø, Norway
Kingsford MJ (1993) Biotic and abiotic structure in the pelagic environment: importance to small fishes. Bull Mar Sci 53: $393-415$

Kingsford MJ (2001) Diel patterns of abundance of presettlement reef fishes and pelagic larvae on a coral reef. Mar Biol 138:853-867

Kingsford MJ, Murdoch RC (1998) Planktonic assemblages. In: Kingsford MJ, Battershill C (eds) Studying temperate marine environments: a handbook for ecologists. Canterbury University Press, Christchurch, p 226-268

Kingsford MJ, Wolanski E, Choat JH (1991) Influence of tidally induced fronts and Langmuir circulations on distribution and movement of presettlement fishes around a coral reef. Mar Biol 109:167-180

Kingsford MJ, Leis JM, Shanks AL, Lindeman K, Morgan S, Pineda J (2002) Sensory environments, larval abilities and local self-recruitment. Bull Mar Sci 70:341-375

Leis JM (1991) Vertical distribution of fish larvae in the Great Barrier Reef Lagoon, Australia. Mar Biol 109:159-166

Leis JM (2002) Pacific coral-reef fishes: the implications of behaviour and ecology of larvae for biodiversity and conservation, and a reassessment of the open population paradigm. Environ Biol Fish 65:199-208

Leis JM, McCormick MI (2002) The biology, behaviour and ecology of the pelagic, larval stage of coral-reef fishes. In: Sale PF (ed) Coral reef fishes: dynamics and diversity in a complex ecosystem. Academic Press, San Diego, CA, p 171-199

Leis JM, Carson-Ewart BM, Cato DH (2002) Sound detection in situ by the larvae of a coral-reef damselfish (Pomacentridae). Mar Ecol Prog Ser 232:259-268

Lobel PS, Robinson AR (1986) Transport and entrapment of fish larvae by ocean mesoscale eddies and currents in Hawaiian waters. Deep-Sea Res 33:483-500

McCormick MI, Milicich MJ (1993) Late pelagic-stage goatfishes: distribution patterns and inferences on schooling behaviour. J Exp Mar Biol Ecol 174:15-42

Sammarco PW, Andrews JC (1988) Localised dispersal and recruitment in Great Barrier Reef corals: the Helix experiment. Science 239:1422-1424

Sponaugle S, Lee T, Kourafalou V, Pinkard D (2005) Florida Current frontal eddies and the settlement of coral reef fishes. Limnol Oceanogr 50:1033-1048

Stobutzki IC, Bellwood DR (1997) Sustained swimming abilities of the late pelagic stages of coral reef fishes. Mar Ecol Prog Ser 149:35-41

Swearer SE, Caselle JE, Lea DW, Warner RR (1999) Larval retention and recruitment in an island population of a coral-reef fish. Nature 402:799-802

Warner RR, Cowen RK (2002) Local retention of production in marine populations: evidence, mechanisms, and consequences. Bull Mar Sci 70:245-249

Willis BL, Oliver JK (1988) Inter-reef dispersal of coral larvae following the annual mass spawning on the Great Barrier Reef. Proc 6th Int Coral Reef Symp 2:853-859

Wolanski E, Hamner WM (1988) Topographically controlled fronts in the ocean and their biological significance. Science 241:177-181

Wolanski E, Imberger J, Heron ML (1984) Island wakes in shallow coastal waters. J Geophys Res 89:10553-10569

Wolanski E, Burrage D, King B (1989) Trapping and dispersion of coral eggs around Bowden Reef, Great Barrier Reef, following mass coral spawning. Cont Shelf Res 9:479-496

Young IR, Black KP, Heron ML (1993) Circulation in the ribbon reef region of the Great Barrier Reef. Cont Shelf Res $14: 117-142$

Submitted: February 28, 2006; Accepted: October 21, 2006

Proofs received from author(s): June 19, 2007 